\title{
Clinical, biochemical, and genetic analysis of two Korean patients with Trichorhinophalangeal syndrome type I and growth hormone deficiency
}

Young Bae Sohn ${ }^{1 *}$, Chang-Seok Ki ${ }^{2}$, Sung Won Park ${ }^{3}$, Sung-Yoon Cho ${ }^{3}$, Ah-Ra Ko ${ }^{4}$, Min-Jung Kwon², Ji-Youn Kim ${ }^{4}$ Hyung-Doo Park², Ok-Hwa Kim², Dong-Kyu Jin ${ }^{3}$

From 7th APPES Biennial Scientific Meeting

Nusa Dua, Bali. 14-17 November 2012

Tricho-rhino-phalangeal syndrome type I (TRPSI) is a rare autosomal dominant hereditary disorder characterized by sparse hair, bulbous nose, long philtrum, thin upper lip, and skeletal abnormalities including cone-shaped epiphyses, shortening of the phalanges, and short stature. TRPSI is caused by mutations in the TRPS1 gene. Herein, we report two Korean cases of TRPSI. Although both patients (a 17-year-old-female and a 14-year-old male) had typical clinical findings, Patient 1 had an additional growth hormone (GH) deficiency. Treatment with recombinant human growth hormone (rhGH) $0.7 \mathrm{IU} / \mathrm{kg} /$ week led to an increase in growth velocity. Over 10 years of GH therapy, the mean growth velocity was $5.7 \pm 0.9 \mathrm{~cm} /$ year. While patient 2 showed a low response after the GH stimulation test, the patient had a poor response with rhGH therapy and GH therapy was discontinued after 6 months.

For the genetic analysis of the TRPS1 gene, two mutations were found. Patient 1 had a heterozygous mutation c.2520dupT (p.Arg841LysfsX3) which had not been previously reported. Patient 2 had a known nonsense mutation c.1630C $>\mathrm{T}$ (p.Arg544X). In summary, we were the first to report Korean patients with mutation of TRPS1.

\footnotetext{
Authors' details

${ }^{1}$ Department of Medical Genetics, Ajou University Hospital, Suwon, Korea. ${ }^{2}$ Department of Laboratory Medicine and Genetics, Sungkyunkwan University School of Medicine, Seoul, Korea. ${ }^{3}$ Department of Pediatrics Samsung Medical Center, Sungkyunkwan University School of Medicine, Seoul, Korea. ${ }^{4}$ Center for Clinical Research, Samsung Biomedical Research Institute, Seoul, Korea. ${ }^{5}$ Department of Radiology, Ajou University Hospital, Suwon, Korea.
}

Published: 3 October 2013

'Department of Medical Genetics, Ajou University Hospital, Suwon, Korea Full list of author information is available at the end of the article
doi:10.1186/1687-9856-2013-S1-P59

Cite this article as: Sohn et al: Clinical, biochemical, and genetic analysis of two Korean patients with Trichorhinophalangeal syndrome type I and growth hormone deficiency. International Journal of Pediatric Endocrinology 2013 2013(Suppl 1):P59.
Submit your next manuscript to BioMed Central and take full advantage of:

- Convenient online submission

- Thorough peer review

- No space constraints or color figure charges

- Immediate publication on acceptance

- Inclusion in PubMed, CAS, Scopus and Google Scholar

- Research which is freely available for redistribution
() Biomed Central 